\title{
Early Stage Steroid Treatment for Acute Facial Paralysis in Korea
}

\author{
Myung Woo Kim and Jin Kim \\ Department of Otorhinolaryngology, Inje University College of Medicine, Ilsan Paik Hospital, Goyang, Korea
}

\section{한국에서의 급성 안면마비 환자에 대한 조기 스테로이드치료의 의미와 중요성}

\author{
김명우 · 김 진 \\ 인제대학교 의과대학 일산백병원 이비인후과학교실
}

\author{
Received December 1, 2015 \\ Revised December 14, 2015 \\ Accepted December 22, 2015 \\ Address for correspondence \\ Jin Kim, MD, PhD \\ Department of Otorhinolaryngology, \\ Inje University College of Medicine, \\ Ilsan Paik Hospital, \\ 170 Juhwa-ro, Ilsanseo-gu, \\ Goyang 10380, Korea \\ Tel $+82-31-910-7114$ \\ Fax $+82-31-910-7518$ \\ E-mail jinsound@gmail.com
}

\begin{abstract}
Facial nerve paralysis is an unexpected or embarrassed disease which unilateral facial musculatures are suddenly or gradually paralyzed by various causes. However, the most common cause of acute facial paralysis is known to be Bell's palsy. Until now, various treatments are recommended to patients with acute facial paralysis. Especially in Asian countries such as Korea, Japan, and China, there are so many patients who be managed by acupuncture therapy as the initial treatment, even if there exists clearly proven steroid therapy that minimizes neural damage and the incidence of permanent facial complications could be reduced. In Korea, various procedures not clearly unverified or unproven such as acupuncture treatment, massage therapy and thermotherapy are performed without standards regimen instead of administering steroid to patients with acute facial paralysis in the early stages. It has been already known that any initial trials with un-established treatment without full understanding of pathophysiology of facial nerve injury worsen prognosis after acute facial paralysis. There are reports showing that the prognosis of Korean patients with Bell's palsy is worse than globally known prognosis of patients with Bell's palsy. Such reports may reflect unverified procedures and consequently putting off steroid treatment in the early stages. Therefore, this is a paper intended to investigate issues occurring in treating a patient with acute facial paralysis in Korea in order to prepare the medical guidelines for the better solution.
\end{abstract}

Korean J Otorhinolaryngol-Head Neck Surg 2016;59(5):346-52

\section{서 론}

안면신경마비는 갑자기 혹은 서서히 일측의 안면 근육이 마 비되는 질환으로서 그 원인은 여러 가지가 있으나 이학적 검 사상 단지 안면 근육의 마비 형태로만 나타나게 되는 특성을 가지고 있어 진단을 위해 세심한 주위가 필요하다. 물론 안면 신경마비를 초래하는 가장 흔한 원인은 벨 마비(Bell's palsy) 로서 전체 안면마비 환자의 약 $51 \%$ 정도를 차지하며(Fig. 1) 그 다음으로 두부외상(head trauma)(22\%), 이성대상포진 (herpes zoster oticus)(7\%), 종양(tumor)(6\%), 감염(infection)
(4\%), 선천성 질환을 포함하여 출생과 연관된 경우(congenital facial palsy or birth trauma)(3.5\%), 편측 안면경련(hemifacial $\mathrm{spasm})(2 \%)$, 중추신경계 병변(1\%), 비전형적인 벨 마비(0.5\%) 의 순으로 빈도를 보이고 기타 독성, 대사성 및 의인성 원인 도 일부를 차지한다. ${ }^{1)}$ 이렇게 다양한 원인에 의해 안면신경 마비가 생기지만 제일 중요한 것은 적절한 치료를 받고 안면 마비 질환이 가능한 그 후유증이 없이 회복이 되어야 그 환 자의 정서적 혹은 사회적인 삶의 질적인 측면에서 진정한 회 복을 보일 수 있다. ${ }^{2)}$

급성 안면신경마비의 치료에 있어서 신경의 병태, 생리학적 


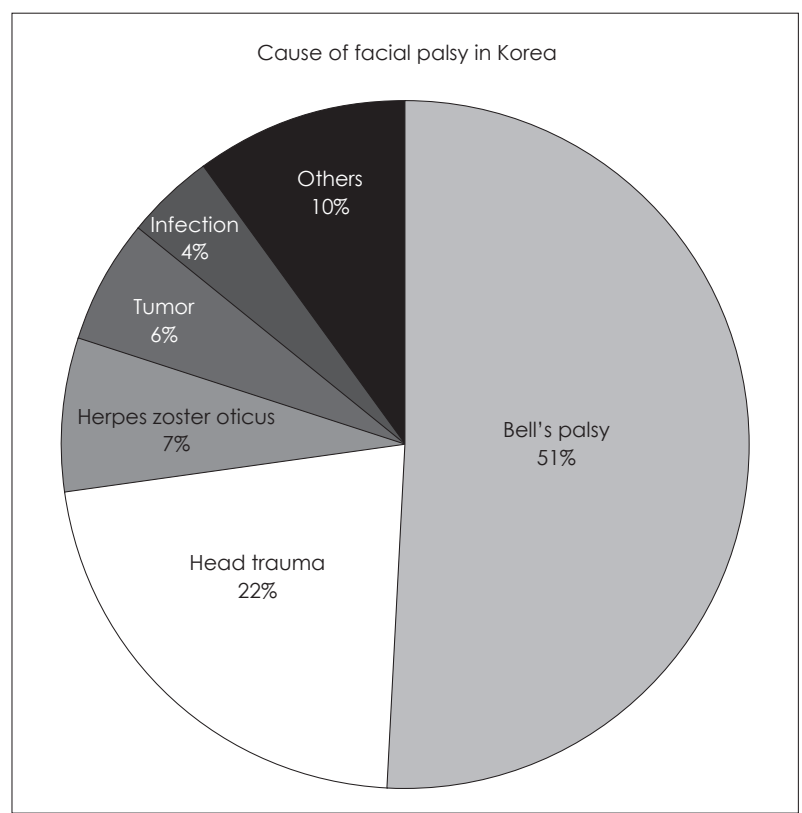

Fig. 1. Cause of facial paralysis in Korea.

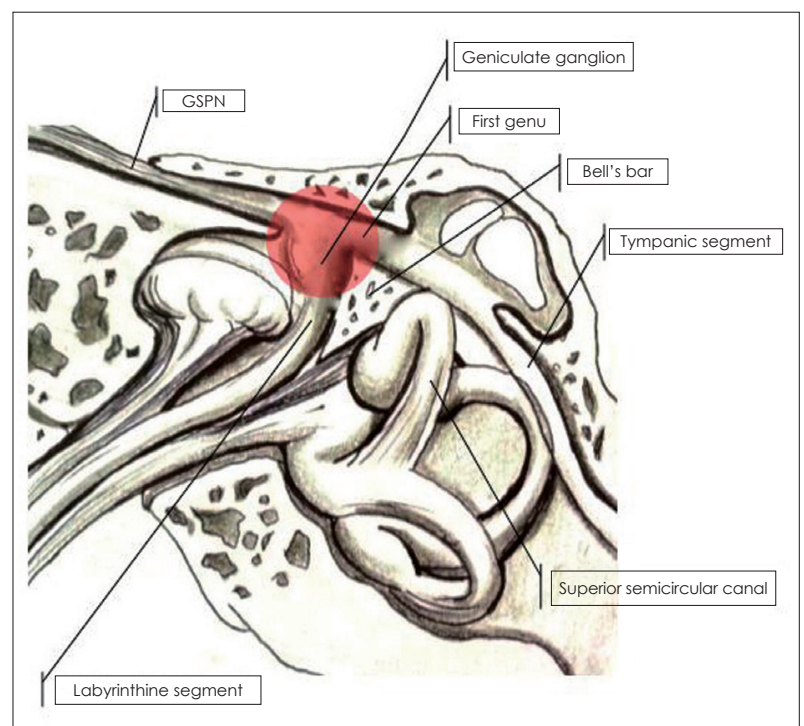

Fig. 2. Herpes virus reactivation in geniculate ganglion.
특성상 치료 시기만큼 중요한 것은 없다. 특히 벨 마비라 알려 진 급성 안면마비는 그 증상이 안면 근육의 마비 증상 외에는 특별한 증상이 없어 환자 입장에서는 뇌경색 또는 뇌출혈 등 의 중추성 병변에 대한 두려움이 앞서 아직 검증이 부족한 치 료를 권유 받거나 혹은 과도한 검사를 권유 받기도 한다. 하지 만 벨 마비는 측두골내 질환으로서 슬상 신경절(geniculate ganglion)에 잠복되어 있던 헤르페스 바이러스의 재활성화 (reactivation)가 안면신경 부종의 주된 원인으로 여겨지고 있으며(Fig. 2), ${ }^{3-5)}$ 안면신경마비를 초래하는 여러 가지 원인을 배제한 후에야 진단할 수 있는 특성을 가지고 있다. 바이러 스 손상에 의한 안면신경마비는 대부분이 저절로 사라지는 자 연 회복의 과정을 거치게 되는 것으로 알려져 있어, 아무 치료 를 받지 않아도 약 $71 \%$ 의 환자에서 완전회복 되며, 약 $84 \%$ 는 정상에 가까운 회복이 이루어지고, ${ }^{6)}$ 약 15 20\%의 환자는 불 완전 회복이 되어 이 환자 군에 대해 주의를 기울여야 한다.

안면신경의 병태 생리학적인 측면에서 고려하였을 때 안면 신경 손상 후 그 운명은 손상되는 순간 결정이 된다 해도 과 언은 아니다. 안면신경이 손상된 경우 다른 말초신경과 같이 손상 정도를 분류할 수 있으며 그 정도에 따라 서로 다르지만 계획된 변성기간(degeneration phase)과 재생기간(regeneration phase)을 가지게 된다. ${ }^{78)}$ 즉 안면신경이 신경내막(endoneurium)을 포함하여 손상을 받게 되면 안면신경은 재생 과정 중에 비정상적 재생(aberrant regeneration), 합선 전송 (ephaptic transmission) 등의 현상이 생기게 되어 안면 근육 에 비정상적인 움직임과 수축이 유발된다. ${ }^{9-11)}$ 하지만 안면신 경 손상 후 안면신경 내 섬유다발이 어떠한 상태에 있느냐를 예측하기는 매우 어려운 경우가 있다. 그 이유는 모든 섬유다 발이 동일한 손상 정도를 가지는 것이 아니라 서로 다른 손상 정도를 가지고 있으며(Fig. 3), 전기생리학적 검사가 생리적 신 경차단(neuropraxia)과 월러 변성(Wallerian degeneration)이 일어나는 축삭절단(axonotmesis)을 구별해 줄 수 있으나, 축 삭절단(axonotmesis)과 신경절단(neurotmesis)을 정확히 구
Fig. 3. The difference between the degree of damage to the nerve bundle in Bell's palsy.

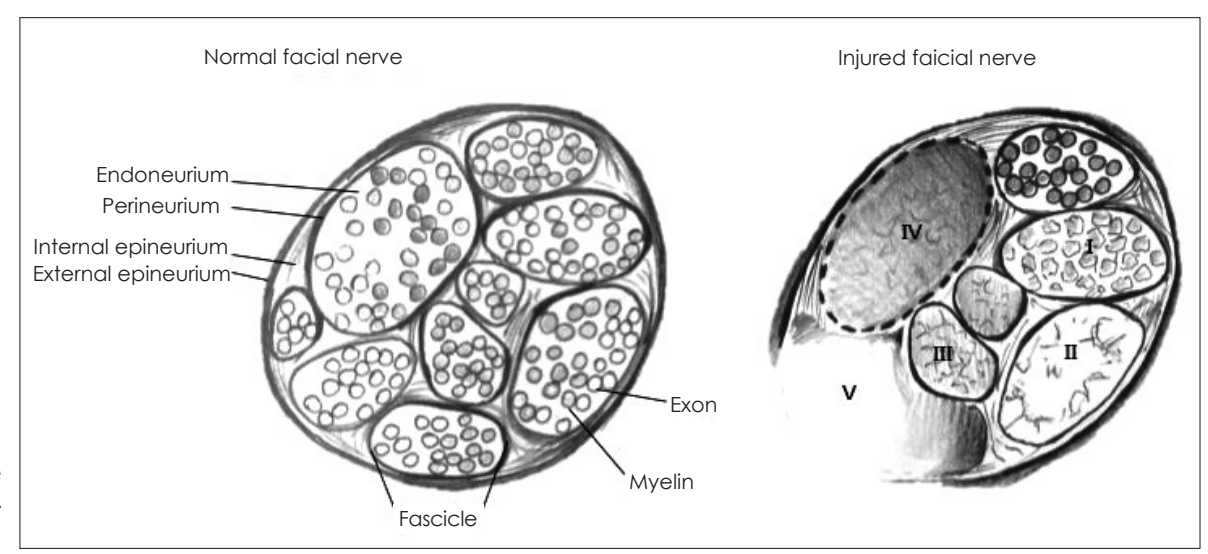


별해 주지는 못하기 때문이다. 다만 안면신경 내에 신경절단 (neurotmesis)의 손상을 가지고 있는 신경 섬유가 많은 비율 로 존재한다면 전기생리학적 검사상 변성 비율(degeneration ratio)이 수일 내 비교적 급격하게 증가하는 것으로 알 수 있으 며 이는 House-Brackmann(HB) facial nerve grading system $\mathrm{V}$ 와 $\mathrm{VI}$ 에 해당되는 상태로서 불완전 회복될 가능성이 높다고 할 수 있다. ${ }^{12-14)}$

결론적으로는 벨 마비 치료 중 제일 중요한 것은 안면 근육 의 마비 이후 약 2 일부터 14 일 사이에 진행되는 월러 변성(Wallerian degeneration)상태의 신경 섬유의 수를 줄여 안면신경 의 완전회복을 돕는 것이다.

2010년부터 2015년까지 벨 마비에 대한 코크란 리뷰(Cochrane's review)를 참고하면 총 6개의 치료에 대한 언급이 되어 있다. 경구 스테로이드 치료, ${ }^{15)}$ 항바이러스제 투여 ${ }^{16)}$ 수술 적 치료, ${ }^{17)}$ 물리치료 ${ }^{18)}$ 침 치료, ${ }^{19)}$ 고농도산소요법 ${ }^{20}$ 이다. 하지 만 유일하게 치료효과가 확실히 있다고 판단되는 것은 일주 일 안에 스테로이드치료를 적절하게 받는 것이라 언급을 하 였고 그 외에 치료에 대해서는 효과가 없거나 있더라도 그 검 증이 아직 미흡한 상태라 결론을 내리고 있다.

조기에 스테로이드 치료(prednisolone, $\mathrm{mg} / \mathrm{kg}$ a day for the first 5 days, tapered thereafter)를 하는 경우 진행되는 신경의 부종을 미연에 방지하여 더 이상의 신경 손상을 최소화하여, 영구적 안면신경마비의 발생 빈도를 감소시키는 것으로 알려 져 있다. ${ }^{21,22)}$ 하지만 항바이러스제재와 스테로이드의 병행요 법 시의 효과에 관해서는 아직 논란의 여지가 많다. 주로 쓰 이는 항바이러스제제(aciclovir, valaciclovir, famciclovir)는 바이러스의 DNA 합성효소를 방해하는 뉴클레오사이드 유사 체(neucleoside analogue)로서 바이러스의 복제(replication) 를 저해시키는데, 안면마비가 생긴지 3일 안에 복용하였을 경우에만 더 이상의 바이러스 복제를 방지할 수 있는 효과가

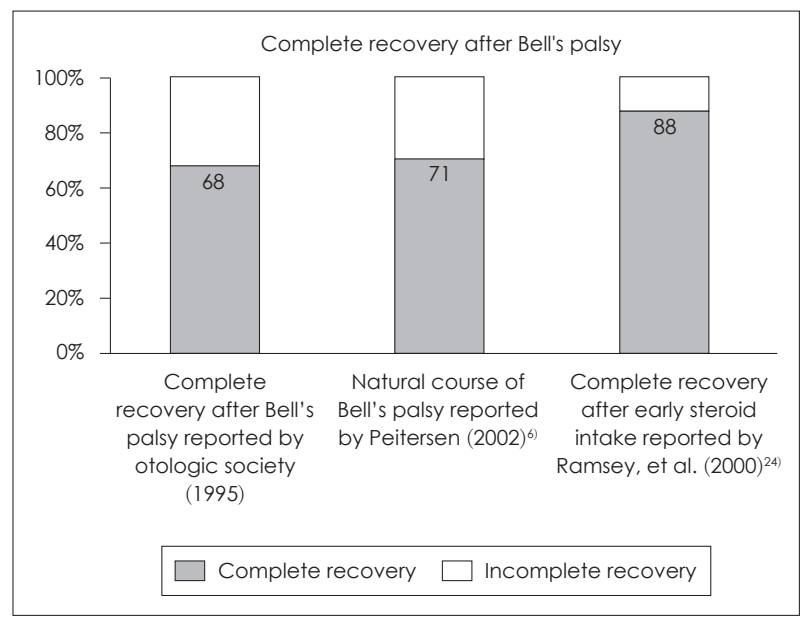

Fig. 4. Recovery rate of the treatment of Bell's palsy.
있으며 바이러스를 근본적으로 없애지는 못한다. ${ }^{23)}$

이러한 점에서 Ramsey 등 ${ }^{24}$ 이 메타분석을 통해 보고한 바와 같이 안면 근육의 마비가 생기고 일주일 안에 적절한 경 구 스테로이드치료를 한 경우 완전회복률이 약 $71 \%$ 에서 $88 \%$ 로 증가한다는 보고는 시사하는 바가 크다. 완전회복률이 약 $17 \%$ 가 증가할 수 있다는 것은 한국에서 매년 6 만여 명의 안 면마비 환자가 발생하는 것을 감안한다면 적절한 스테로이 드 치료에 약 9 천에서 1 만 명 정도는 완전회복의 기회를 더 가질 수 있다는 것으로 해석할 수 있다(Fig. 4).

\section{본 론}

\section{한국에서의 벨 마비 치료의 문제점}

1995년 벨 마비 118 case의 다기관 연구(5개 대학병원)를 통 해 대한이과학회에서 발표한 보고에 의하면 약 $68 \%$ 가 완전 회복, $32 \%$ 가 불완전 회복이 되었고 그 이유는 초기에 스테로 이드 치료가 이루어지지 않은 상당수의 환자가 있었기 때문 이라고 결론을 내렸다. ${ }^{25)}$ 불완전 회복이라 함은 앞서 언급한 바와 같이 HB grade I이 아닌 후유증이 남아 있는 모든 상태 를 말하는 것이며 안면 비대칭성과 동조현상, 안면 근육의 근력 저하 등이 포함되는 것으로서 기존의 많은 국내나 국외 논문에서 HB grade II 이상을 예후 좋은 회복이라 판단하고 완전회복의 집단에 포함하여 발표하였던 바가 있다. 그러나 실 제로 환자에게서는 HB grade I과 HB grade II는 매우 큰 차 이이며, 불완전 회복이 되어 치료를 원하는 수많은 환자 대부 분인 HB grade II이다. 대부분의 안면마비에 대한 국내, 외 논문에서는 HB grade I, II가 좋은 예후, HB grade III, IV 중증도, $\mathrm{HB}$ grade $\mathrm{V}, \mathrm{VI}$ 는 고도 나쁜 예후로 나누는 것을 마 치 관례처럼 보고하고 있으나, 환자 입장에서는 HB grade II 로 남는 것은 절대 좋은 예후로 받아들여지지 않으며 더욱 더 많은 치료를 원하고 있기 때문에 본 논문에서는 완전회복과 불완전 회복으로만 나누어 설명하는 바이다.

물론 앞서 이과학회에서 보고하였던 바는 대학병원에서의 진행이었기 때문에 표본선정편파(selection bias)가 있어 벨 마 비 환자에 대한 대표성이 결여된 표본이라고 보여지나 이를 감안하더라도 벨 마비의 자연적인 과정에 의한 완전회복률 (71\%)보다 횔씬 낮은 수치라고 볼 수 있다(Fig. 4).

연세대학교 이비인후과교실에서 지난 2000년 3월부터 2011 년 3월까지 약 560여 명의 벨 마비 환자에 대한 데이터를 추적 분석하였고, 또한 인제대학교 이비인후과 교실에서는 2013년 3월부터 2015년 3월까지 벨 마비를 않고 약 1년 이상 회복이 되지 않은 벨 마비 후유증으로 본원에 내원한 환자 198명을 대상으로 설문조사를 시행한 바가 있다. 
우선 연세대학교 이비인후과 교실에서 벨 마비로 진단된 환 자 560명 중 96명이 $\mathrm{HB}$ grade $\mathrm{V}$ 이상의 중증 안면마비 환자 였으며, 이 중 24 명이 발병 1 주 이내 적절한 스테로이드 치료 를 받았으며(group A), 8명은 발병 1주 이내 적절한 스테로이 드 치료와 함께 2주 이내에 안면신경 감압술을 시행 받았고 (group B), 17명은 발병 1주 이내 적절한 스테로이드 치료는 하 였으나 2주가 지나 안면신경 감압술을 시행받았고(group C), 나머지 47명은 초기에 적절한 스테로이드 치료가 이루어지지 않았다(group D).

1 년 이상의 추적 관찰한 결과 이 네 group 간의 완전회복률 은 서로 차이가 있는데 group $\mathrm{A}$ 의 경우 $34.6 \%$, group B의 경우 $37.5 \%$, group C의 경우 $29.4 \%$, group $\mathrm{D}$ 의 경우 $17.7 \%$ 의 완전회복률을 보이고 있었으며, 특히 group A, B, C 간에 차 이는 통계적으로 없으나 group $\mathrm{D}$ 와 다른 group 간에 차이는 존재하였다. 이 차이는 정확히 1 주 이내 스테로이드를 쓴 여 부에 따라 달라지는 것으로 여겨지며 초기에 안면신경 감압 술 여부 혹은 감압술 시기에 의한 차이는 불충분한 자료이거 나 혹은 결과에 차이가 없다고 해석할 수 있다. Cochrane review와 동일한 결과로서 1주 이내 적절한 스테로이드 치료 가 중증 안면마비의 예후에 영향을 준다고 볼 수 있으며 그 외 치료는 큰 의미가 없다(Table 1).

두 번째로 인제대학교 이비인후과학교실에서 벨 마비 후
안면마비 후유증으로 내원한 환자 198명을 조사한 결과, 초기 전기신경전도검사(electroneuronography, $\mathrm{ENoG}$ )가 $90 \%$ 이 상의 degeneration ratio를 가지고 있던 환자가 약 162 명으로 약 $82 \%$ 이며, 환자의 과거력상 8 명을 제외한 대부분이 $\mathrm{HB}$ grade V 이상의 중증 안면마비를 가지고 있었다. 또한 198명 의 환자 중 $51 \%$ 에 해당되는 약 101 명이 1 주 안에 스테로이드 를 적절하게(prednisolone, $\mathrm{mg} / \mathrm{kg}$ a day for the first 5 days, tapered thereafter) 복용하였고 49\%에 해당되는 환자 97명 이 스테로이드 복용을 하지 못하였다. 즉 초기에 중증 안면 신경마비를 않고 있는 환자의 약 절반 정도는 스테로이드조 차 제대로 복용하지 못하였다는 것이다. 처음 초기 치료로서 스테로이드 치료를 받지 못하였다는 것은 한국에서 중증 안 면마비 치료에 대한 정확한 가이드라인이 부재하기도 하지만 여러 다양한 의료기관에서 각자 나름대로의 치료를 시행하고 있기 때문이라 볼 수 있다. 심한 벨 마비 이후 회복되지 않은 환자의 $51 \%$ 에 해당되는 50 명의 환자들이 처음 방문하여 치료 한 곳은 개인 및 준·종합 한의원으로서 침 치료를 몇 주간 받았으며, 약 $25 \%$ 에 해당되는 24명의 환자는 가까운 응급실 을 방문하여 검사를 시행받고도 적절한 스테로이드 투여가 이루어지지 않았으며, $24 \%$ 에 해당되는 환자 23명은 그 외 민 간치료 및 마사지요법, 온열요법 등이나 스테로이드가 없는 경 구 약물을 받아 복용하였다(Fig. 5). 심한 안면마비가 있음에

Table 1. Complete recovery rate after severe Bell's palsy

\begin{tabular}{lcccc}
\hline \multicolumn{1}{c}{ HB grade V, VI $(n=96)$} & \multicolumn{2}{c}{ Optimal management $(n=34)$} & \multicolumn{2}{c}{ Different strategies $(n=62)$} \\
\hline Group & $\mathrm{A}(26)$ & $\mathrm{B}(8)$ & $\mathrm{C}(17)$ & $\mathrm{D}(45)$ \\
Start steroid from onset & $4.7 \pm 1.4$ & $3.6 \pm 1.7$ & $6.8 \pm 3.2$ & $17.6 \pm 5.3$ \\
Surgical intervention & - & $6.2 \pm 2.4$ & $27.6 \pm 12.5$ & - \\
End result (rate of complete recovery) & $34.6 \%(9 / 26)$ & $37.5 \%(3 / 8)$ & $29.4 \%(5 / 17)$ & $17.7 \%(8 / 45)$ \\
\hline
\end{tabular}

Group A (Steroid Tx within 1 week), Group B (Steroid Tx within 1 week+decompression within 2 weeks), Group C (Steroid Tx within 1 week+decompression after 2 weeks), Group D (Different strategies or other therapies)

Fig. 5. Early steroid medication rate who visit treatment for Bell's palsy in Inje University Hospital.

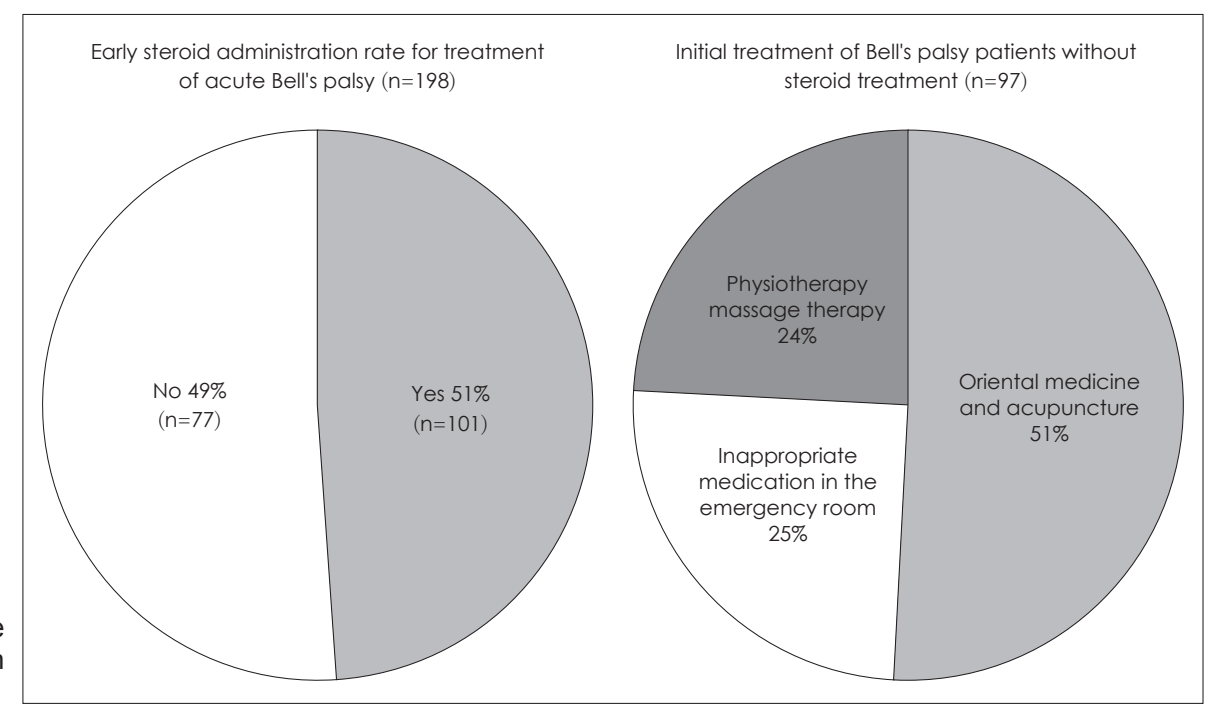


도 불구하고 전기생리학적 검사를 시행받아 본적이 없다고 답한 경우도 약 $38 \%$ 에 해당되는 75 명이었으며, 이는 안면마 비의 정도에 따른 분류조차 이루어지지 않고 있다는 것을 반 증하고 있다.

$\mathrm{Fisch}^{26)}$ 와 Gantz 등 ${ }^{12)}$ 이 언급한 바와 같이 모든 안면신경 의 운명은 손상 후 2 3주 안에 결정지어 진다고 해도 과언은 아니다. 즉 왈러 변성(Wallerian degeneration)이 종료되기 전 안면신경의 손상을 최소화해야 한다는 것이고 그 역할은 조 기 적절한 스테로이드 투여에 의해 이루어질 수 있다.

이러한 관점에서 한국에서의 초기 벨 마비 치료의 문제점 은 두 가지 측면으로 요약할 수 있다, 첫 번째로, 무작위배정에 의한 이중맹검연구(randomized, double blind, placebo-controlled trials) 없는 다양한 치료에 대한 검증의 부재이며, 두 번째는 이러한 검증이 미흡한 치료를 중증도에 상관없이 기 관별 특성에 따라 접근한다는 것이다. 이는 결국 현재로서는 확실하게 효과가 있다고 입증이 된 조기 적절한 스테로이드 투여에 의한 높은 완전회복률을 저하시킬 수밖에 없으며, 그 피해는 환자의 불완전 회복으로 이어진다.

\section{한국에서의 벨 마비 치료에 대한 해결방안}

벨 마비가 HB grade IV 이하의 경우 대부분의 안면신경 섬 유가 신경차단(neuropraxia) 혹은 축삭절단(axonotmesis)의 상태이기 때문에 초기에 적절한 스테로이드 치료만 한다면 시 간이 경과할수록 신경재생이 비교적 완전하게 이루어져 그 외의 치료는 Cochrane review에서 권장한 바와 같이 큰 의
미가 없다. 하지만 $\mathrm{HB}$ grade $\mathrm{V}$ 이상의 중증 안면마비의 경우 는 대부분의 신경 섬유가 신경절단(neurotmesis) 혹은 축삭 절단(axonotmesis)의 상태이기 때문에 적절한 스테로이드 치료를 하더라도 신경재생이 완전하게 이루어지지 않게 되어 안면 근육에 후유증이 남게 되는 경우가 많은데, 하물며 초 기에 적절한 스테로이드 치료마저 기회를 놓친다면 더욱 더 심한 부종으로 안면신경에 심한 전기적 결손이 생기게 된다.

2015년 Cochrane's databases of systemic reviews를 각 치료별로 간략히 살펴보면 Table 2 와 같다. 현재 한국에서는 벨 마비의 치료에 확실히 검증이 되어 있는 스테로이드 투여 가 우선 보편적이고 필수적으로 이루어져야 할 것이며, 그 외 효과가 미미하거나 검증이 되어 있지 않은 항바이러스제, 수 술적 치료, 물리치료, 침 치료 고농도산소요법 등은 각 의료 기관의 특성에 맞게 스테로이드 치료와 더불어 추가될 수 있 는 부가적인 치료가 되어야 할 것으로 사료가 된다. 하지만 이러한 검증이 미흡한 치료들을 각 의료기관의 주된 치료로 전이가 된다면 벨 마비 환자의 예후는 보장이 되지 않을 뿐 아니라 환자는 정신적으로 매우 큰 혼란에 빠지게 될 것이다.

또한 벨 마비의 예후인자 중 가장 중요한 검사인 전기생리 학적 검사가 모든 환자에게 적용이 되어야 한다. 전기신경전도 검사 $(\mathrm{ENoG})$ 의 변화는 안면신경의 왈러 변성(Wallerian degeneration)이 진행이 되고 있는 신경 다발의 비율을 알 수 있는데, 병변이 심하여 급속히 진행되는 경우 왈러 변성이 5일 만에 종료가 되나 서서히 진행되는 경우 2주 혹은 3주 뒤에 종 료가 되어 단지 왈러 변성이 진행하고 있는 기간 동안 의미가

Table 2. 2015 Cochrane Database of systematic reviews

\begin{tabular}{|c|c|}
\hline Treatment & Author's conclusion by cochrane database of systematic reviews (June, 2015) \\
\hline Corticosteroids & $\begin{array}{l}\text { The available evidence from randomized controlled trials shows significant benefit from treating } \\
\text { Bell's palsy with corticosteroids. }\end{array}$ \\
\hline Antiviral treatment & $\begin{array}{l}\text { Moderate-quality evidence from randomised controlled trials showed no additional benefit from } \\
\text { the combination of antivirals with corticosteroids compared to corticosteroids alone or with } \\
\text { placebo, and no benefit from antivirals alone compared to placebo, for the treatment of Bell's } \\
\text { palsy. Moderate-quality evidence showed a small but just significant benefit of combination } \\
\text { therapy compared with corticosteroids alone in severe Bell's palsy. We found no significant } \\
\text { increase in adverse events from the use of antivirals compared with either placebo or } \\
\text { corticosteroids. }\end{array}$ \\
\hline $\begin{array}{l}\text { Surgical interventions for } \\
\text { the early management }\end{array}$ & $\begin{array}{l}\text { There is only very low quality evidence from randomised controlled trials and this is insufficient to } \\
\text { decide whether surgical intervention is beneficial or harmful in the management of Bell's palsy. } \\
\text { Further research into the role of surgical intervention is unlikely to be performed because } \\
\text { spontaneous recovery occurs in most cases. }\end{array}$ \\
\hline Physical therapy & $\begin{array}{l}\text { There is no evidence of significant benefit or harm from any physical therapy for idiopathic facial } \\
\text { paralysis. The possibility that facial exercise reduces time to recover and sequelae needs } \\
\text { confirming with good quality randomised controlled trials. }\end{array}$ \\
\hline Acupuncture & $\begin{array}{l}\text { The quality of the included trials was inadequate to allow any conclusion about the efficacy of } \\
\text { acupuncture. More research with high quality trials is needed. }\end{array}$ \\
\hline $\begin{array}{l}\text { Hyperbaric oxygen } \\
\text { therapy }\end{array}$ & $\begin{array}{l}\text { Very low quality evidence from one trial suggests that hyperbaric oxygen therapy may be an } \\
\text { effective treatment for moderate to severe Bell's palsy, but this study was excluded as the } \\
\text { outcome assessor was not blinded to treatment allocation. Further randomised controlled } \\
\text { trials are needed. }\end{array}$ \\
\hline
\end{tabular}


Table 3. Assessment of Bell's palsy

\begin{tabular}{|c|c|c|}
\hline History & Physical examination & Testing/imaging \\
\hline - Type of injury & - Previous incisions and scars & - Electroneurography (within 2 weeks) \\
\hline - Time since injury & - Integrity of trigeminal, vagal, and & - Electromyography (for more than 1 year) \\
\hline - Age, overall health, life expectancy & hypoglossal nerves & - CT and MRI (temporal bone and parotid, \\
\hline - Nutritional factors & - Facial motion, tone, structure & if there is any question about the cause of \\
\hline $\begin{array}{l}\text { - Previous operative report, radiation } \\
\text { therapy }\end{array}$ & - Status of eye & paralysis) \\
\hline
\end{tabular}

있는 검사로서 전기신경전도검사상 변성비율(degeneration ratio)을 알아보는 것은 매우 중요하다. 뿐만 아니라 진행 속도 또한 매우 중요한 예후 인자로서 급속히 진행이 되는 경우 매 일 검사하여 연속된 신경전도 검사상 운동섬유가 정상측의 $10 \%$ 미만이 5 일 이내에 도달되는 경우 혹은 근전도 검사(electromyograph)상 근세동전위(fibrillation potentials), 양성 예 각파-(positive sharp wave) 등의 근육의 탈신경(denervation) 전위가 보일 경우, ${ }^{26-28)}$ 다른 내과적 질환 혹은 생명에 치명적인 외상이 없을 경우에 안면신경 감압술을 시행할 수도 있다. ${ }^{29)}$ 따 라서 안면신경의 특성과 손상에 의해 발생되는 일련의 변화를 파악하고 적절하게 그 예후를 예측하는 것이 매우 중요하다.

한국에서 벨 마비 환자를 적절히 치료하기 위해서는 우선적 으로 환자에 대한 정확한 평가가 이루어져야 하며 이를 위해 자세한 문진, 이학적 검사 및 방사선 검사와 함께 전기생리학 적 검사가 필요하다(Table 3). 문진을 통하여 안면마비의 정도 와 시점, 환자의 나이, 전반적인 건강상태 및 기대 수명, 영양상 태, 수술 및 방사선 치료에 대한 과거력 등을 알아볼 수 있으 며, 이학적 검사를 통하여 과거 수술의 흔적과 반흔, 삼차신 경, 미주신경, 설인신경 등의 상태, 안면 근육의 움직임과 구조, 안구 및 안륜근의 상태를 확인할 수 있고, 근전도 검사를 통 하여 안면신경 및 근육의 기능을 알아보고 CT 및 MRI 검사 를 통하여 안면신경의 형태학적인 상태와 그 주위 구조물과 의 관계, 이하선 등의 상태를 면밀히 알아볼 수 있다. ${ }^{30,31)}$

\section{결 론}

안면신경마비 중 가장 많은 형태인 벨 마비(idiopathic facial nerve palsy, Bell's palsy)는 10만 명당 20 30명이 매년 발생이 되는 것으로 보고되고 있으며, ${ }^{32-34)}$ 모든 연령에서 발병 이 가능하나, 10 세 이전의 유아나 노인에게서는 발병이 보다 적고, ${ }^{6,35)}$ 임신, 당뇨, 과거의 기왕력 등은 벨 마비의 고 위험군 으로 여겨지고 있다. $32,36,37)$

벨 마비는 안면신경마비를 초래하는 여러 가지 원인을 배 제한 후에야 진단할 수 있으며, 그 예후를 예측하기는 매우 힘 든 경우가 많다. 현재 벨 마비의 치료로는 조기 적절한 스테로 이드 치료만이 입증이 되어 적극 권장하는 치료 방법이라 할
수 있다. ${ }^{6,15-20,24)}$

물론 다양한 치료를 스테로이드와 병행요법할 시 스테로이 드 단독 치료보다 안면신경마비 후 회복이 더 빠르며, 완전회 복의 비율이 더 높다는 보고도 많이 있으나, ${ }^{38-40)}$ 유일하게 검 증된 스테로이드 투여가 주된 치료로 이루어져야 할 것이다. 그 외 효과가 미미하거나 검증이 되어 있지 않은 치료 방법 등 은 각 의료기관의 특성에 맞게 스테로이드 치료와 더불어 추 가될 수 있는 부가적인 치료가 될 수 있으나, 검증이 아직 미 흡한 치료들을 각 의료기관의 주된 치료로 전이가 된다면 벨 마비 환자의 완전회복률은 저하될 수밖에 없으며 그 피해는 환자의 안면 근육의 불완전 회복으로 이어지게 되어 시간이 지남에 따라 안면에 뜻하지 않은 비대칭과 동조현상을 유발 하여 환자의 사회적인 활동 및 경제적인 활동에 막대한 영향 을 줄 수 있다.

\section{REFERENCES}

1) Lee WS, Kim J. Facial nerve paralysis and surgical management. J Korean Med Assoc 2009;52(8):807-18.

2) Kim J, Lee HR, Jeong JH, Lee WS. Features of facial asymmetry following incomplete recovery from facial paralysis. Yonsei Med J 2010;51(6):943-8

3) Adour KK, Wingerd J. Idiopathic facial paralysis (Bell's palsy): factors affecting severity and outcome in 446 patients. Neurology 1974;24(12):1112-6.

4) Sullivan FM, Swan IR, Donnan PT, Morrison JM, Smith BH, McKinstry B, et al. Early treatment with prednisolone or acyclovir in Bell's palsy. N Engl J Med 2007;357(16):1598-607.

5) Selesnick SH, Patwardhan A. Acute facial paralysis: evaluation and early management. Am J Otolaryngol 1994;15(6):387-408.

6) Peitersen E. Bell's palsy: the spontaneous course of 2,500 peripheral facial nerve palsies of different etiologies. Acta Otolaryngol Suppl 2002;(549):4-30.

7) Seddon H. Surgical Disorders of the Peripheral Nerves. 2nd ed. Edinburgh: Chuchill and Livingston;1972.

8) Sunderland S. Nerves and Nerve Injuries. 2nd ed. Edinburgh: Churchill and Livingston; 1978.

9) Montserrat L, Benito M. Facial synkinesis and aberrant regeneration of facial nerve. In: Jankovic J, Tolos E, editors. Advances in Neurology. New York, NY: Raven Press;1988. p.211-24.

10) May M. Management of facial hyperkinesis: overview of hyperkinesis. In: May M, Schaitkin B, editors. The Facial Nerve. New York: Thieme; 2000. p.431-9.

11) Moran CJ, Neely JG. Patterns of facial nerve synkinesis. Laryngoscope 1996;106(12 Pt 1):1491-6.

12) Gantz BJ, Rubinstein JT, Gidley P, Woodworth GG. Surgical management of Bell's palsy. Laryngoscope 1999;109(8):1177-88 
13) McCabe BF. Injuries to the facial nerve. Laryngoscope $1972 ; 82(10)$ : 1891-6.

14) Eberstein A, Pachter BR. The effect of electrical stimulation on reinnervation of rat muscle: contractile properties and endplate morphometry. Brain Res 1986;384(2):304-10.

15) Salinas RA, Alvarez G, Daly F, Ferreira J. Corticosteroids for Bell's palsy (idiopathic facial paralysis). Cochrane Database Syst Rev 2010; (3):CD001942.

16) Gagyor I, Madhok VB, Daly F, Somasundara D, Sullivan M, Gammie $\mathrm{F}$, et al. Antiviral treatment for Bell's palsy (idiopathic facial paralysis). Cochrane Database Syst Rev 2015;11:CD001869.

17) McAllister K, Walker D, Donnan PT, Swan I. Surgical interventions for the early management of Bell's palsy. Cochrane Database Syst Rev 2011;(2):CD007468.

18) Teixeira LJ, Valbuza JS, Prado GF. Physical therapy for Bell's palsy (idiopathic facial paralysis). Cochrane Database Syst Rev 2011;(12): CD006283.

19) Chen N, Zhou M, He L, Zhou D, Li N. Acupuncture for Bell's palsy. Cochrane Database Syst Rev 2010;(8):CD002914.

20) Holland NJ, Bernstein JM, Hamilton JW. Hyperbaric oxygen therapy for Bell's palsy. Cochrane Database Syst Rev 2012;2:CD007288.

21) Adour KK, Ruboyianes JM, Von Doersten PG, Byl FM, Trent CS, Quesenberry CP Jr, et al. Bell's palsy treatment with acyclovir and prednisone compared with prednisone alone: a double-blind, randomized, controlled trial. Ann Otol Rhinol Laryngol 1996;105 (5):371-8.

22) Hato N, Yamada H, Kohno H, Matsumoto S, Honda N, Gyo K, et al. Valacyclovir and prednisolone treatment for Bell's palsy: a multicenter, randomized, placebo-controlled study. Otol Neurotol 2007;28(3): 408-13.

23) Alberton DL, Zed PJ. Bell's palsy: a review of treatment using antiviral agents. Ann Pharmacother 2006;40(10):1838-42.

24) Ramsey MJ, DerSimonian R, Holtel MR, Burgess LP. Corticosteroid treatment for idiopathic facial nerve paralysis: a meta-analysis. Laryngoscope 2000;110(3 Pt 1):335-41.

25) Kim HN, Chang SO, Lee WS. Facial nerve symposium. Seoul: Ilji
Munwha Printing Co; Basic and clinical management;1995. p.129-75. 26) Fisch U. Prognostic value of electrical tests in acute facial paralysis. Am J Otol 1984;5(6):494-8.

27) Coker NJ, Fordice JO, Moore S. Correlation of the nerve excitability test and electroneurography in acute facial paralysis. Am J Otol 1992; 13(2):127-33.

28) Canter RJ, Nedzelski JM, McLean JA. Evoked electromyography in Bell's palsy: a clinically useful test? J Otolaryngol 1986;15(6): 344-7.

29) Fisch U. Surgery for Bell's palsy. Arch Otolaryngol 1981;107(1):1-11.

30) Lang J. Anatomy of the brainstem and the lower cranial nerves, vessels, and surrounding structures. Am J Otol 1985;Suppl:1-19.

31) Nelson JR. Facial paralysis of central nervous system origin. Otolaryngol Clin North Am 1974;7(2):411-24.

32) Holland NJ, Weiner GM. Recent developments in Bell's palsy. BMJ 2004;329(7465):553-7.

33) Chan EH, Tan HM, Tan TY. Facial palsy from temporal bone lesions. Ann Acad Med Singapore 2005;34(4):322-9.

34) Marson AG, Salinas R. Bell's palsy. West J Med 2000;173(4):266-8.

35) Prescott CA. Idiopathic facial nerve palsy (the effect of treatment with steroids). J Laryngol Otol 1988;102(5):403-7.

36) Adour K, Wingerd J, Doty HE. Prevalence of concurrent diabetes mellitus and idiopathic facial paralysis (Bell's palsy). Diabetes 1975; 24(5):449-51.

37) Pitts DB, Adour KK, Hilsinger RL Jr. Recurrent Bell's palsy: analysis of 140 patients. Laryngoscope 1988;98(5):535-40.

38) De Diego JI, Prim MP, De Sarriá MJ, Madero R, Gavilán J. Idiopathic facial paralysis: a randomized, prospective, and controlled study using single-dose prednisone versus acyclovir three times daily. Laryngoscope 1998;108(4 Pt 1):573-5.

39) Antunes ML, Fukuda Y, Testa JRG. Clinical treatment of Bell's palsy: comparative study among valaciclovir plus deflazacort, deflazacort and placebo. Acta AWHO 2000;19:68-75.

40) Zhou P. Aciclovir in treating Bell's palsy. Chin J New Drugs Clin Remedies 1999;18:13-4. 